\title{
AVALIAČ̃̃ DA INCIDÊNCIA DE BRUCELOSE E DE BACILOS ÁLCOOL-ÁCIDO RESISTENTES NOS ABATEDOUROS MUNICIPAIS DA REGIÃO DE UMUARAMA - PARANÁ: DADOS PRELIMINARES.
}

\section{E.M.G. CIFFONI'; A.P. SILVEIRA²; J.P. SILVA² ${ }^{2}$; M.C. PEREIRA ${ }^{2}$}

${ }^{1}$ Disciplina de Doenças Infecciosas e Bioclimatologia Animal, Curso de Medicina Veterinária. ${ }^{2}$ Acadêmicos de Medicina Veterinária, Universidade Paranaense - UNIPAR, Umuarama-PR.

O Estado do Paraná caracteriza-se por ser um dos estados brasileiros com bom serviço de inspeção sanitária. Desde a implantação da Responsabilidade Técnica, exercida por Médicos Veterinários, no início da década de 90 , o índice de diagnóstico das diversas enfermidades de interesse em Saúde Pública tem aumentado consideravelmente. Doenças como tuberculose e brucelose, além de trazerem prejuízos econômicos à pecuária paranaense, são também de grande importância sob o ponto vista de Saúde Pública. O abate ocorrido nos abatedouros municipais são constantemente acompanhados pelo Médico Veterinário, que quando necessário, condena as carcaças com lesões provenientes de enfermidades infecciosas ou não. Em trabalhos realizados em outros estados brasileiros foram encontrados uma incidência média de $2,62 \%$ de bacilos álcool-ácidos resistentes (tuberculose) nos rebanhos abatidos em abatedouros municipais, já a incidência de brucelose é difícil de ser avaliada em médias confiáveis, já que as exigências pré-abate, como atestados e exames específicos, mesmo sendo exigidos pela saúde pública, muitas vezes não são respeitados, podendo também variar em função da qualidade dos animais abatidos e de sua procedência, mas sabe-se que é relativamente alta. Com o objetivo de levantar a incidência destas duas importantes doenças na região de Umuarama foram colhidas amostras de sangue de 116 bovinos, sendo aproximadamente $20 \%$ do total geral abatido na região. Procedeu-se também à preparação de lâminas através de material colhido com $s w a b$ estéril da faringe dos animais abatidos, para posteriormente serem coradas pelo método de Ziehl-Nielsen. Amostras de fezes também foram colhidas e posteriormente coradas pelo mesmo método. A incidência de brucelose foi avaliada pelo método de prova rápida, através dos antígenos Tipo Acidificado e Acidificado Tamponado, tendo como resultados preliminares os seguintes dados: Número de animais avaliados: $116(100 \%)$; número de animais positivos para soro acidificado: 16 (13.8\%); animais positivos para acidificado tamponado: $12(10.34 \%)$; animais com titulação 1/25: 14 (12.06\%); animais com titulação 1/50: 10 (11.6\%); animais com titulação 1/100: 2 (1.74\%); animais negativos para antígeno acidificado: 90 (77.58\%); animais negativos para antígeno acidificado tamponado: 104 (89.65\%); Para avaliação de incidência de bacilos álcool-ácido resistentes (tuberculose) foram preparadas 232 lâminas de fezes e de material (muco) de faringe colhido por swab. Destas, 25 (10.78\%) foram lidas, sendo que todas tiveram diagnóstico negativo. 